\title{
Defining and Advancing the Study and Practice of Sustainability Management
}

\author{
David Benjamin Billedeau ${ }^{1} \&$ Juan Moreno-Cruz ${ }^{1}$ \\ ${ }^{1}$ University of Waterloo, Canada \\ Correspondence: David Benjamin Billedeau, University of Waterloo, Canada.
}

Received: December 28, 2021

Accepted: February 5, $2022 \quad$ Online Published: February 17, 2022

doi:10.5539/jms.v12n1p52

URL: https://doi.org/10.5539/jms.v12n1p52

\begin{abstract}
We define the new field of sustainability management in reference to the more well-known concept of sustainable development. We argue that a sustainability management lens - predicated on the preservation of manufactured and natural capital (and integrative of concepts of weak and strong sustainability) - is vital in advancing academic and practical aspects of sustainable development. Sustainability management embodies the activities and processes required to reach the goal of sustainable development. The field of sustainability management is ultimately framed as fundamental in advancing environmental and corporate governance systems aimed at providing current and future generations with an equitable level of access to manufactured and natural capital. We identify the need to develop a practice of sustainability management that guides political, economic, social, technological and legal aspects of human activity towards sustainable development.
\end{abstract}

Keywords: sustainability management, sustainable development, adaptive governance, environmental governance, corporate governance, corporate social responsibility, natural capital, manufactured capital

\section{Introduction}

Sustainable development (SD) and sustainability management (SUSM) are related but distinct concepts. As identified in the Brundtland Report, SD is synonymous with intragenerational and intergenerational equity (Brundtland, 1987; Kates et al., 2005). Although there are numerous interpretations of SD (Ayres et al., 2001; Jabareen, 2008), we define SD as the goal of providing future generations with an equitable level of access to both manufactured and natural capital that ensures needs (economic, environmental, and social) are satisfied. We define SUSM as a multidisciplinary and multi-stakeholder field of study and practice that is continuously evolving to account for the growing spectrum of stakeholders dedicated to supporting SD and the relationships between them. We argue that a SUSM lens, which values the preservation of both manufactured and natural capital and integrates concepts of weak and strong sustainability, is necessary to advance the practice and study of adaptive governance systems needed to achieve SD. Beyond governance, we stress the need to develop the practical elements of SUSM designed to align unsustainable human activities - as determined by the SUSM lens-with SD.

The first task for us is to develop a comprehensive definition of SUSM. We begin our analysis by developing an understanding of humanity's relationship with the natural world and related multifaceted efforts to protect shared resource systems. We argue that SUSM theory blends divergent disciplines to support a multidisciplinary and multi-stakeholder approach to promoting SD. We then examine SUSM's polycentric approach to meeting stakeholder needs to highlight the field's tendency to create SD solutions for stakeholders at the individual, organizational, and societal levels. Our understanding of SUSM theory suggests the practice of SUSM requires localized and contrasting approaches to SD.

Our second task is to ground SUSM in the context of SD. We argue that a SUSM lens conceptualizes SD issues through the spectrum of weak sustainability (WS) and strong sustainability (SS). To support this argument, we examine opposing views on the value of manufactured and natural capital in two steps. First, we illustrate the capacity and limitations for WS to support SD. Second, we discuss the risks SS creates towards manufactured capital alongside the need to protect natural capital. By contrasting the two sides of the WS and SS spectrum, we propose that a SUSM lens accepts that current and future generations require equitable access to both manufactured and natural capital and siloed approaches, as evidenced in the WS/SS dichotomy, are unable to balance the needs of SD stakeholders. A SUSM lens is thus beneficial for identifying opportunities to align 
-political, economic, social, technological, environmental, and legal aspects of human activity (Note 1) along a spectrum of sustainability to better preserve and harmonize manufactured and natural capital.

With the definition and theoretical conceptualization of SUSM established, our last task is to apply the SUSM lens we propose here to the subtopics of environmental governance and corporate governance (Note 2). In both cases, a SUSM lens is useful in revealing the limitations of governance systems grounded in rigid value systems and theories to support the preservation of both manufactured and natural capital.

We first apply a SUSM lens to environmental governance systems predicated on technocentrism to highlight the limitations of a technocentric approach to preserving natural capital. In our analysis, the rebound effect and intergenerational discounting emerge as clear indicators of the failure of technocentrism to support the intergenerational transfer of natural capital. When we apply the SUSM lens to environmental governance systems predicated on ecocentrism, the concept of degrowth reveals the limitations of ecocentric governance systems to support the preservation of manufactured capital. Ultimately, technocentric and ecocentric approaches to environmental governance fail to recognize the complementary nature of manufactured and natural capital. A SUSM lens thus reveals opportunity to advance scholarship on blended approaches to environmental governance.

We then apply a SUSM lens to corporate governance systems predicated on shareholder theory. As our analysis shows, corporate governance systems that fail to integrate socio-economic and environmental considerations into business practices provide limited - if any-value for the long-term preservation of manufactured and natural capital. We then apply a SUSM lens to corporate governance systems based on stakeholder theory to demonstrate potential synergies between the private sector and the preservation of manufactured and natural capital. Corporate sustainability practices such as shared value creation (SVC), environmental management systems, and life cycle assessments (LCAs) provide examples of how the private sector can support continued operations as well as the preservation of manufactured and natural capital. However, concerns pertaining to the value of corporate social responsibility (CSR) programs - as well as greenwashing and lobbying - highlight that corporate governance systems cannot ensure alignment between corporate business practices and the preservation and harmonization of manufactured and natural capital. In this case, a SUSM lens reveals the need for continued scholarship on flexible corporate governance systems that better operate on a weak and strong sustainability spectrum.

We conclude with a discussion on the deficiencies in siloed approaches to environmental and corporate governance, which fail to simultaneously preserve manufactured and natural capital. Our discussion stresses that a multifaceted SUSM lens is useful in advocating for continued scholarship in adaptive governance and practices that better protect manufactured and natural capital for current and future generations.

\section{Defining Sustainability Management}

SUSM is a nascent field that provides stakeholders at the individual, organizational, and societal levels with the tools to measure and manage environmental and socio-economic issues (Starik \& Kanashiro, 2013) while simultaneously serving as a platform to advocate for more radical, transformational changes within societal and economic systems (Seyfang, 2009). Starting from the core values and principles of SD identified in the Brundtland Report (Kates et al., 2005), SUSM can be defined as a multidisciplinary and multi-stakeholder field of study and practice that is continuously evolving based on the integration of (and relationships between) a growing field of stakeholders dedicated to addressing environmental stewardship and sustainable development issues. As a result, SUSM contains "a number of contradictions and complexities" intrinsic to its nature (Byl \& Slawinski, 2015, p. 73). The components of this definition will be further elaborated, starting with developing an understanding of humanity's relationship with the natural world and related multifaceted efforts to protect shared resource systems.

\subsection{Humanity's Relationship with Nature}

Strategies for protecting shared resource systems are often centered on differing perspectives of humanity's relationship with nature. One perspective sees humans as incapable of supporting shared resources without strong government intervention or coercive actions. A Hobbesian approach to environmental stewardship would require individual freedoms to be surrendered to a sovereign government tasked with implementing coercive actions to protect shared resource systems. In effect, human nature requires restraint to avoid ruining shared resource systems. Olson asserts that shared interests could only be secured in small societies through coercive tactics incentivizing individuals to support the interests of the wider public as opposed to narrow self-interest (Olson, 1965). Hardin expands this view and asserts that unappeasable self-interest, boundless individual freedom, and a dearth of coercive tactics designed to curb humanity's impact on the planet will eventually result 
in the collapse of Earth systems (Hardin, 1968). Both Olson and Hardin believe that human nature makes it impossible to protect shared resource systems. However, there are alternative views for how best to leverage human nature to protect the environment.

Another perspective sees humans as capable of agreeing in community rules to govern access to shared resources. In this Ostromian perspective, rules generated from within communities are more effective than rules imposed on a community from external stakeholders (Herzberg, 2020; Ostrom, 2015). In this view, there are numerous governance systems that can protect shared resource systems based on local community institutions engaging with state and scientific entities and without the need for Hobbes's Leviathan (Dietz et al., 2017). This perspective rejects uniform approaches to environmental stewardship. Ostrom asserts that "neither the state nor the market is uniformly successful in enabling individuals to sustain long-term, productive use of natural resource systems" (Ostrom, 2015, p. 1). A dispersed, regional approach to environmental stewardship aligns with the views espoused by Rittel and Webber - who argue that there is no single, objective approach to advancing a common good, as needs and morals are different between and within societies (Rittel \& Webber, 1973).

While Olson, Hardin, and Hobbes advocate for the protection of shared resource systems through curbing the excesses of human nature, Dietz et al., Herzberg, Ostrom, and Rittel and Webber recognize the need to leverage humanity's dynamic community approaches to governance. The Ostromian perspective of environmental stewardship predicated on a multifaceted, decentralized network of governance systems better reflects SUSM's multidisciplinary and multi-stakeholder qualities, as discussed below.

\subsection{Multidisciplinary and Multi-Stakeholder}

SUSM is multidisciplinary because the field seeks to address environmental issues that transcend different academic and professional subjects (e.g., ecology, political science, business, etc.). One of the focal issues of SUSM is the Anthropocene, a new period of Earth's history characterized by the discernible impact humanity in planetary systems such as the climate (Crutzen, 2002; Steffen et al., 2018). When assessing the Anthropocene, SUSM requires a multidisciplinary approach to understand the complexities of climate through mathematics, science, and physics; moreover, the drivers and impacts of climate change must also be examined using many differing fields of study (Burroughs, 2001).

SUSM is also a multi-stakeholder approach to environmental governance. The United Nations Office of Sustainable Development notes that multi-stakeholder partnerships are a "powerful mechanism to achieve transformation" (United Nations Office for Sustainable Development, 2020, p. 77) that allows for the mobilization and sharing of knowledge and financial resources in support of advancing the SDGs. Within the field of SUSM, stakeholders (individuals and groups) come from different academic disciplines and different public and private sector organizations at the local, national, and international levels. In effect, SUSM does not require a single, central governing institution but instead relies upon a polycentric network of different stakeholders to advance a common set of principles pertaining to environmental stewardship.

The multidisciplinary and multi-stakeholder nature of SUSM is required for achieving a sustainable future. While the definition of "sustainability" is subject to ongoing debate and change (Ayres et al., 2001), the meaning of "sustainable development" is often drawn from the 1987 Brundtland Report, which defined the term as "development that meets the needs of the present without compromising the ability of future generations to meet their own needs" (Brundtland, 1987). This support of intergenerational equity is embedded within the SDGs. Established in 2015, the SDGs provide a roadmap for the international community to alleviate poverty, protect the environment, and ensure economic prosperity by 2030 (United Nations, n.d.). As noted by Nilsson et al, the 17 SDGs are interlinked and must be advanced as a collective (rather than individually) to avoid "perverse outcomes" (Nilsson et al., 2016, p. 320). These interlinkages are further examined by Stafford-Smith et al, who highlights interlinkages across sectors, across societal actors, and between countries (including countries of varying income levels) in order to assert that a systems view is required to support implementation of the SDGs (Stafford-Smith et al., 2017). Gibson provides a clear example of these interlinkages by noting that much like the alleviation of poverty requires more than economic analysis, environmental stewardship requires more than a biophysical approach (Gibson, 2009, p. 261). To that end, the success or failure of the SDGs ultimately relies upon the integration of multiple disciplines and stakeholders (e.g., public, private, individual, organizational, state, and non-state) to address the series of interconnected issues the SDGs are trying to ameliorate (Burch et al., 2014; Chan et al., 2019; Kates et al., 2005).

While SUSM is aligned with transnational efforts such as the UN SDGs, the field transcends international sustainable development initiatives. SUSM will continue to evolve based on the ongoing interactions of stakeholders and disciplines, worsening risks towards shared resource systems, and a developing understanding 
of these risks. The disciplines and stakeholders associated with SUSM will continue to evolve in tandem with continued insights on environmental stewardship and sustainable development issues. However, the core tenants of SUSM that have been described above, namely the support for locally generated governance arrangements, multidisciplinary and multi-stakeholder approaches to supporting sustainable development and environmental stewardship, will remain.

\section{A Sustainability Management Lens}

The intent of this section is to develop a critical SUSM lens that values both manufactured and natural capital. We assert that a SUSM lens examines issues of SD along the spectrum of Weak Sustainability (WS) and Strong Sustainability (SS). To support this assertion, we begin by providing an overview of WS and SS to highlight the conceptual differences between these two approaches to SD. We then study the capacity and limitations of WS and SS to support intergenerational equity. Finally, we demonstrate how a SUSM lens is useful in examining whether specific human activity supports SD through the preservation of manufactured and natural capital as well as identifying opportunities to modify human activity to support SD.

\subsection{Manufactured and Natural Capital}

Natural capital can be understood as the finite raw materials required for industrial production; more broadly, natural capital can include resources and ecosystems integral to the continued wellbeing of humanity (Dietz \& Neumayer, 2007). Manufactured capital can be viewed as the products, services, and financial returns created via industrial processes dependent on raw materials. WS and SS support differing views on the substitutability of manufactured and natural capital. WS supports the view that natural capital can be substituted so long as future generations are provided with a material benefit in the form of manufactured capital. SS does not allow for such substitutions and asserts that economic systems cannot be sustained through continued environmental exploitation and that future generations should be afforded access to natural capital (Ayres et al., 2001; Dietz \& Neumayer, 2007).

\subsection{Weak Sustainability}

WS generates potential risks and benefits towards the preservation of manufactured capital. The Republic of Nauru serves as an example of how natural capital can be substituted to provide future generations with manufactured capital. The Pacific island experienced economic growth over the $20^{\text {th }}$ century due to intensive mining. While mining resulted in significant environmental decay, a trust fund was established using the generated income (Ayres et al., 2001). Nauru also provides an example of the risks associated with engaging in WS practices. A continental economic crisis destroyed most of the fund financed by the mining efforts, and Nauru was left with a decimated environment (Ayres et al., 2001). Future generations of Nauruans will not have access to the same level of natural or manufactured capital as their forbearers; thus, while WS was employed on the island, intergenerational equity was ultimately not secured.

Despite the poor outcome for Nauru, WS can still support the preservation of natural capital. For example, Norway's robust pension fund is made possible through revenues of the nation's oil and gas operations (Richardson, 2011). The Norway model demonstrates a clear substitution of natural capital for manufactured capital that may provide material financial benefits to multiple generations. Similarly, carbon markets have the potential to create financial incentives to mitigate carbon emissions while generating revenue to support societal welfare (Spaargaren \& Mol, 2013). Importantly, carbon markets are not designed to eliminate carbon emissions altogether - they simply disincentivize emissions while providing financial returns to offset the environmental impact of carbon intensive activities (Wang et al., 2017). In sum, WS does not eliminate environmental pressures caused by human activity, but it can generate manufactured capital for future generations to partially and imperfectly offset the loss of natural capital.

\subsection{Strong Sustainability}

Limited understanding of the feasibility and structure of SS systems could create risks towards the preservation of manufactured capital. Extreme forms of SS could be untenable to the continuation of modern society (Gray, 2010), whereas more moderate approaches would merely restrict the substitution of critical natural capital for manufactured capital (Pelenc \& Ballet, 2015). Critical natural capital is an integral component to the wellbeing of ecosystems required for continued human wellbeing (Dietz \& Neumayer, 2007; Pelenc \& Ballet, 2015). It can be argued that recent policy decisions to prohibit construction of the Keystone XL pipeline were an example of SS - as the potential risks to the environment were deemed to be against the national interests of the United States (Monga, 2021). Yet despite such conceptualizations of SS, a practical strategy outlining how to navigate the uncertainty and scale of SS transitions has not been devised. However, SS aim of preserving natural capital 
can be integrated into adaptive governance systems.

Recognition of the value of both manufactured and natural capital corresponds with calls to support hybrid and multifaceted approaches to SD (Gladwin et al., 1995). SUSM's role in supporting sustainable transitions is to integrate and optimize WS and SS concepts across differing stakeholders, economic sectors, and systems. To do so, a SUSM lens must identify opportunities to align activities and processes on a spectrum of sustainability.

\subsection{Applying the Sustainability Management Lens}

A SUSM lens focuses on determining whether human activities, e.g., environmental or corporate governance systems, support the preservation of manufactured and natural capital for future generations. Beyond reflection, action is central to SUSM's value as a field of study and practice.

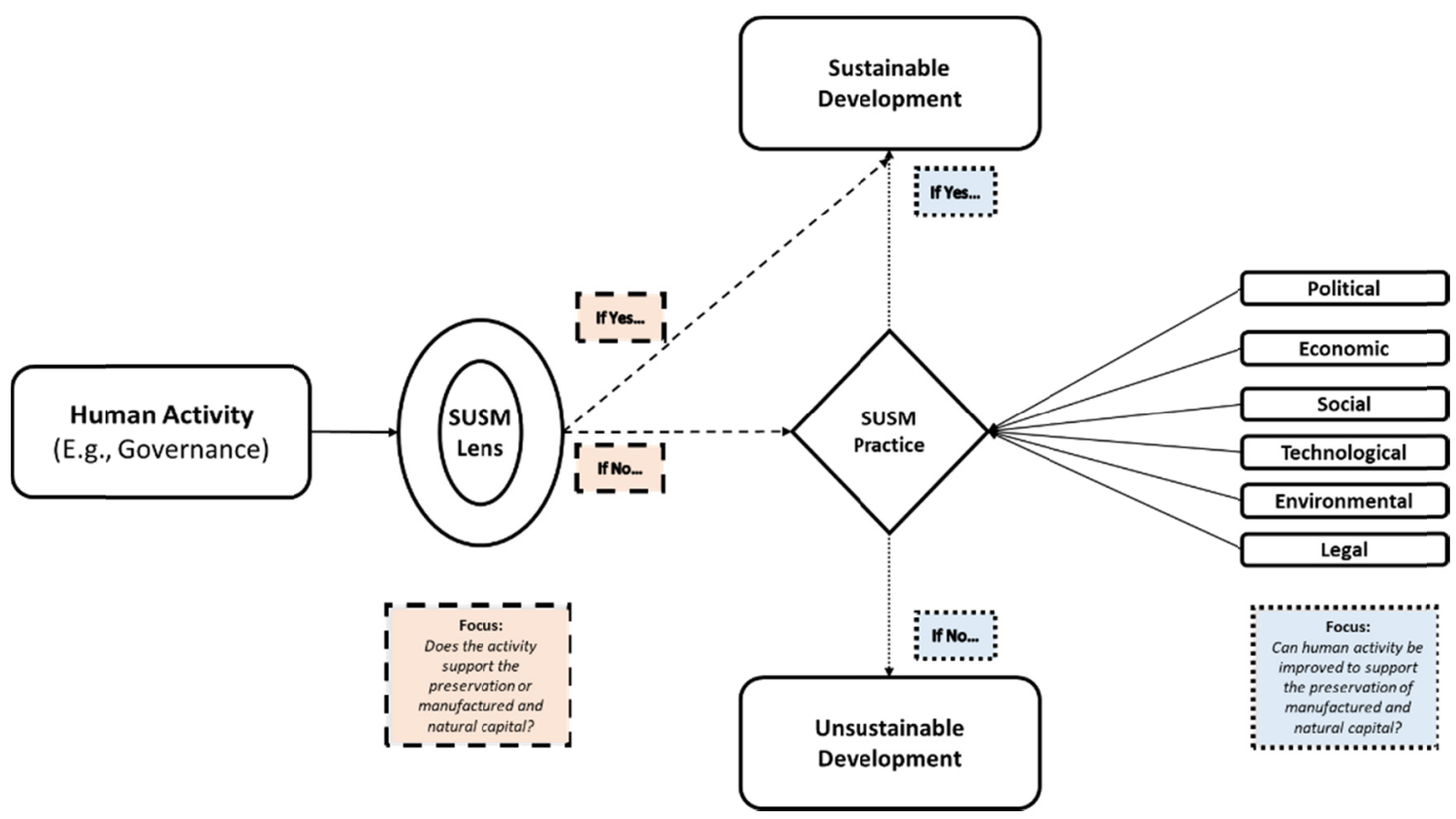

Figure 1. SUSM as a field of study and practice

As noted in Figure 1, a SUSM lens can examine whether specific human activities (e.g., actions and behaviors,) support SD (i.e., preserve manufactured and natural capital for future generations) or do not (i.e., exhaust manufactured and natural capital for future generations). The considerations used to determine alignment with the WS-SS spectrum are varied. To examine whether human activity does or does not support SD, SUSM (as a field of practice) should embrace the complex interactions between political, economic, social, technological, environmental, and legal aspects of the activity. For each activity examined under a SUSM lens, a binary question is asked: does this activity fall within the WS-SS spectrum by preserving a balance between natural and manufactured capital. If an activity is identified as unsustainable, then PESTEL aspects are examined individually and in tandem to diagnose areas of improvement. A SUSM lens thus highlights whether human activity is focused on intergenerational equity and creates opportunities for the operationalization of SUSM to ameliorate unsustainable development practices.

In the next section, a SUSM lens is applied to environmental and corporate governance systems to determine whether existing structures balance and preserve both forms of capital for future generations.

\section{Opportunities to Advance New Governance Systems}

Governance is a central topic within the field of SUSM that refers to the ability of actors (e.g., governments and organizations) to create and administer rules (Burch et al., 2014; Fukuyama, 2013). The intent of this section is to examine two subtopics of governance: environmental governance and corporate governance. In both cases, a SUSM lens reveals siloed approaches to environmental and corporate governance systems that are unable to support a holistic view of SD that will provide future generations with access to manufactured and natural capital. 


\subsection{Environmental Governance}

Environmental governance pertains to the implementation and performance of rules supporting the wellbeing of the environment and society (Bennett \& Satterfield, 2018). Technocentrism and ecocentrism offer contrasting approaches to environmental governance.

\subsubsection{Environmental Governance (Technocentrism)}

Rooted in neoclassical economic theory, technocentric environmental governance support the preservation of manufactured capital via a technological approach to SD (Emetumah, 2017; Gladwin et al., 1995; Illge \& Schwarze, 2006). A technocentric view is grounded in the belief that perpetual technological innovations will be able to mitigate and repaire environmental damage caused by human activity (Costanza, 1989). Technocentrism is unable to support social, ethical, or behavioural changes to prevent environmental issues from emerging (Chertow, 2000; Gladwin et al., 1995). A SUSM lens focused on the preservation of manufactured and natural capital reveals two issues with a technocentric approach to environmental governance: the rebound effect and discounting.

The rebound effect is perhaps best examined in the use of electric vehicles (EVs). As the cost to drive is lower than traditional powertrains, EV owners often rely on personal transportation more than they otherwise would (Ivanova et al., 2016). Not only are the efficiency improvements of EVs offset by increased usage, there are also concerns about the lifecycle costs of EVs in comparison to traditional fuel vehicles (Hawkins et al., 2013). The rebound effect limits the ability of technology to protect natural capital and notes that efficiency improvements are often accompanied by increased resource consumption (Hertwich, 2005). Therefore, technological advancements alone may fail to provide net environmental benefits (Binswanger, 2001).

Discounting translates future values into modern monetary values (Goulder \& Stavins, 2001), which creates inherent intergenerational conflict by allowing the current generation to prescribe future value to manufactured and natural capital. The discount rate used to support policy decisions is contentious, as higher rates place less emphasis on future benefits and more on current costs. Although a discount rate of zero would ensure that value and impact of investments would be the same for both current and future generations, there are also issues with this approach. Notably, a null discount rate fails to set parameters on time-in effect, a discount rate of zero would require modern sacrifices to support the interests of generations thousands of years from now (Pearce et al., 2003). In sum, high discount rates favor the wellbeing of current generations, and a discount rate of zero will perpetually disenfranchise modern society. Discounting is thus innately opposed to intergenerational equity as it provides modern society with the sole discretion of determining the value of manufactured and natural capital for future generations without consideration for future preferences (Pearce et al., 2003).

\subsubsection{Environmental Governance (Ecocentrism)}

Rooted in ecological economic theory, ecocentric environmental governance supports transforming economic, political, and social systems to address environmental issues (Costanza, 1989; Emetumah, 2017; Gladwin et al., 1995; Illge \& Schwarze, 2006). In so doing, environmental governance systems aligned with ecocentrism are focused on preserving natural capital for future generations (Gladwin et al., 1995; Illge \& Schwarze, 2006). This view is best represented by the degrowth movement.

Degrowth protects natural capital at the cost of manufactured capital. Degrowth promotes a causal relationship between economic growth and environmental decay which requires restrictions on continued substitution of natural capital. Global economic growth has largely been achieved through industrialization predicated on the exploitation of natural resources (Allen, 2008; Schandl et al., 2016; Smil, 2017). Economic growth is measured using metrics associated with wealth (e.g., income levels, gross domestic product) (Hammer \& Pivo, 2017). However, economic performance does not necessarily translate to qualitative increases in quality of life or long-term improvements for society as a whole (Singh \& Eisenmenger, 2010). Further, global economic systems reliant on unlimited economic growth via the exploitation of finite resources ultimately threaten Earth systems vital for human survival (Hsiang \& Kopp, 2018; Steffen et al., 2015; Vörösmarty et al., 2010). For these reasons, advocates for degrowth call for reduced consumption and production in order to protect Earth systems and human wellbeing (Gibbs \& O’Neill, 2017). Environmental governance systems mandating degrowth would result in future generations receiving more natural capital than current and WS practices would provide; however, the financial impact to nations, organizations, and individuals could be severe. A SUSM lens reveals that environmental governance systems promoting degrowth would be unable to support the preservation of manufactured capital and limit the capacity of future generations to thrive. 


\subsection{Corporate Governance}

Corporate governance pertains to the implementation of rules and norms governing the relationship between the private sector and related stakeholders (e.g., employees, shareholders, governments, community, etc.) (Monks \& Minow, 2011). Shareholder theory and stakeholder theory provide conflicting views on the role of the private sector in society.

\subsubsection{Corporate Governance (Shareholder Theory)}

Shareholder theory provides current generations with access to manufactured capital. Under the shareholder theory, the only role of firms is to generate profit (Friedman, 1970). The "input-output" model aligns with Friedman's logic and only requires a firm to transactionally interact with its employees, investors, and suppliers to deliver products to consumers (Donaldson \& Preston, 1995). While corporate governance systems predicated on shareholder theory allow for the continued production of goods and services for a finite period (until natural resources are exhausted), narrow views on profit maximization can result in limited availability of both manufactured and natural capital for future generations.

\subsubsection{Corporate Governance (Stakeholder Theory)}

The stakeholder theory advocates for the creation of shared value between businesses and society, which can support the protection of natural capital while maintaining modern economic systems. The stakeholder model (which aligns with stakeholder theory) requires a firm to interact more materially with a wider network of stakeholders (e.g., governments, unions, communities) (Donaldson \& Preston, 1995). SVC creates economic incentives for firms while simultaneously creating benefits for society and the environment. An example of SVC is seen in a review of Walmart's reduction of product packaging, which created both environmental and economic benefits (Porter \& Kramer, 2011). SVC can also be seen in the widespread use of environmental management systems (e.g., ISO 14001) and LCAs, both of which serve to provide benefits to corporations and their supply chains (e.g., standardized approaches to environmental management and regulatory compliance) while also mitigating environmental impacts of operations (Morrow \& Rondinelli, 2002). Accordingly, corporate governance systems predicated on stakeholder theory allow firms to protect (and in some cases enhance) their financial performance while simultaneously preserving natural and manufactured capital. However, there are concerns about the efficacy of corporate sustainability initiatives such as CSR.

The definition of CSR is varied (Bansal \& Song, 2017; Dahlsrud, 2008; Porter \& Kramer, 2006) and continues to evolve over time (Carroll, 1999). Yet CSR can simply be viewed as corporate initiatives that are: (a) distinct (but not disconnected) from the financial interest of a firm and (b) designed to support socio-economic and/or environmental issues (Billedeau \& Wilson, 2021). Corporate governance systems predicated on stakeholder theory encourage corporations to support the protection of manufactured and natural capital through CSR initiatives; however, these initiatives often provide limited value. CSR initiatives are often shallow and fail to create long-term change or benefits (Porter \& Kramer, 2011). For example, the validity of CSR programs is questioned by research noting that corporate philanthropic initiatives often amount to little more than tax avoidance (Sikka, 2010). Worse, CSR can often be used to mask the true negative impacts of corporate operations.

The use of greenwashing and lobbying provide further evidence that existing corporate governance systems predicated on stakeholder theory fail to ensure the alignment of private sector operations and the preservation of manufactured and natural capital. Greenwashing can be viewed as communication practices designed to mask poor environmental performance (Delmas \& Burbano, 2011). An example of greenwashing can be seen in the use of eco-labels. A case study examining the use of third party eco-labels in the forestry sector of Brazil, Indonesia, and Côte d'Ivoire concludes that the use of eco-labeling did not result in any material change in operations or environmental impact (e.g., deforestation) (van der Ven et al., 2018). The inefficacy of eco-labeling is made worse by firms shifting away from independent third-party environmental certifications in favor of creating in-house eco-brands that are merely designed to serve as an advertisement tool, rather than a meaningful strategy to support SD (Subramanian, 2019). Large firms also employ lobbyists to delegitimize the findings of environmental scientists and weaken environmental regulations (Oreskes \& Conway, 2015). Without corporate oversight, there is the potential for stakeholder corporate governance systems to appear supportive of aligning their operations along a spectrum of sustainability without doing so. In sum, existing corporate governance systems predicated on stakeholder theory fail to ensure the alignment of business operations with the preservation of manufactured and natural capital, which highlights the need for further scholarship better coupling the interests of the private sector with SD. 


\section{Discussion}

Applying a SUSM lens on environmental and corporate governance systems highlights that existing, siloed approaches to governance fail to holistically support SD. A SUSM lens reveals a need to develop adaptive governance systems that support the preservation of manufactured and natural capital. A SUSM lens also reveals opportunities for the practical implementation of SUSM. The practice of SUSM must be equipped to align political, economic, social, technological, environmental, and legal factors of human activity with SD. The breadth of these factors underscores the need for SUSM to be a multidisciplinary and multistakeholder field of study and practice - as no single stakeholder nor academic/professional background is equipped to examine (much less ameliorate) such complexities.

In terms of environmental governance, a SUSM lens revealed limitations of systems predicated on technocentrism and ecocentrism to preserve both natural and manufactured capital. Technocentrism supports the mitigation of environmental impacts caused by human activity but does not ensure the prevention of further environmental decay. The ability of a technocentric approach to SD to support the equitable maintenance of manufactured and natural capital is diminished by the rebound effect and concerns over discounting. Conversely, ecocentrism appreciates the intrinsic connection between humanity and the natural world and seeks to preserve natural capital for future generations. While ecocentric approaches to SD draw attention to the root causes of environmental pressures, governance systems predicated on ecocentrism could fail to preserve manufactured capital if degrowth policies are enforced. As a result of these limitations to protect both forms of capital, a SUSM lens supports continued scholarship on blended approaches to SD that can be applied to environmental governance systems.

As for corporate governance, a SUSM lens focused on the preservation of manufactured and natural capital revealed limitations on systems predicated on shareholder and stakeholder theories. Governance systems predicated on shareholder theory fail to ensure that future generations will have access to manufactured and natural capital. Alternatively, governance systems predicated on stakeholder theory support the alignment of corporate, environmental, and societal interests. While there are examples of corporations aligning with stakeholder theory using SVC, LCA, and environmental management systems, limited enforcement mechanisms within corporate governance systems present risks towards manufactured and natural capital as evidenced in ineffective CSR programs, greenwashing and corporate lobbying. Accordingly, a SUSM lens is useful in advancing (and advocating for) scholarship on governance systems and SUSM practices that address the incongruences between the private sector and SD.

\section{Conclusion}

We argued in this paper that a SUSM lens-predicated on the preservation of manufactured and natural capital and integrative of concepts of weak and strong sustainability - is useful in advancing the practice and study of environmental and corporate governance systems aimed at providing current and future generations with an equitable level of access to both natural and manufatured capital.

We highlighted the centrality of preserving the competing needs of diverse stakeholders within the theory and practice of SD and SUSM. Subsequently, we argued that a SUSM lens conceptualizes SD issues through the spectrum of WS and SS. We demonstrated that an SUSM lens values the preservation of both manufactured and natural capital, as both are vital to ensuring the needs of current and future generations. To that end, as SUSM continues to develop, further scholarship will be required on connecting the SUSM lens (which identifies sustainable and unsustainable development activities) and the practical implementation of SUSM (which attempts to correct unsustainable development practices).

We concluded that a SUSM lens highlights the inability of siloed environmental and corporate governance systems to support a holistic conception of SD. Consequently, there is an opportunity to advance scholarship on adaptive forms of governance that support transitions away from a state of decay onto a spectrum of sustainability, wherein stakeholders protect manufactured and natural capital for future generations. Adaptive governance systems must perpetually integrate and optimize WS and SS theories and practices across differing stakeholders, economic sectors, and systems to ensure a cumulative advancement of SD.

\section{References}

Allen, R. C. (2008). Global Economic History: A Very Short Introduction. Journal of Chemical Information and Modeling, 53(9), 287. https://doi.org/10.1017/CBO9781107415324.004

Ayres, R. U., Van Den Bergh, J. C. J. M., \& Gowdy, J. M. (2001). Strong versus weak sustainability: Economics, natural sciences, and "consilience." Environmental Ethics, 23(2), 155-168. 
https://doi.org/10.5840/enviroethics200123225

Bansal, P., \& Song, H. C. (2017). Similar but not the same: Differentiating corporate sustainability from corporate responsibility. Academy of Management Annals, 11(1), 105-149. https://doi.org/10.5465/annals.2015.0095

Bennett, N. J., \& Satterfield, T. (2018). Environmental governance: A practical framework to guide design, evaluation, and analysis. Conservation Letters, 11(6), e12600. https://doi.org/10.1111/conl.12600

Billedeau, D. B., \& Wilson, J. (2021). COVID-19 and Corporate Social Responsibility: A Canadian Perspective. In W. Leal Filho (Ed.), COVID-19: Paving the Way for a More Sustainable World. Springer Publishing. https://doi.org/10.1007/978-3-030-69284-1_2

Binswanger, M. (2001). Technological progress and sustainable development: What about the rebound effect? Ecological Economics, 36(1), 119-132. https://doi.org/10.1016/S0921-8009(00)00214-7

Brundtland, G. H. (1987). Report of the World Commission on Environment and Development: Our Common Future. United Nations General Assembly Document A/42/427, 17.

Burch, S., Shaw, A., Dale, A., \& Robinson, J. (2014). Triggering transformative change: A development path approach to climate change response in communities. Climate Policy, 14(4), 467-487. https://doi.org/10.1080/14693062.2014.876342

Burroughs, W. J. (2001). Climate change: A multidisciplinary approach. Cambridge University Press. https://doi.org/10.1017/CBO9781139163989

Carroll, A. B. (1999). Evolution of a Definitional Construct. Business \& Society, 38(3), 268-295. https://doi.org/10.1177/000765039903800303

Chan, S., Boran, I., van Asselt, H., Iacobuta, G., Niles, N., Rietig, K., ... Wambugu, G. (2019). Promises and risks of nonstate action in climate and sustainability governance. Wiley Interdisciplinary Reviews: Climate Change, 10(3), 1-8. https://doi.org/10.1002/wcc.572

Chertow, M. R. (2000). The IPAT equation and its variants: Changing views of technology and environmental impact. Journal of Industrial Ecology, 4(4), 13-29. https://doi.org/10.1162/10881980052541927

Costanza, R. (1989). What is ecological economics? Ecological Economics, 1(1), 1-7. https://doi.org/10.1016/0921-8009(89)90020-7

Costanza, R., Daly, H., Folke, C., Hawken, P., Holling, C. S., \& McMichael, A. J. (2000). Managing Our $\begin{array}{llll}\text { Environmental } & \text { Portfolio. } & \text { BioScience, } & \text { 50(2), }\end{array}$ https://doi.org/10.1641/0006-3568(2000)050[0149:MOEP]2.3.CO;2

Dahlsrud, A. (2008). How corporate social responsibility is defined: An analysis of 37 definitions. Corporate Social Responsibility and Environmental Management, 15(1), 1-13. https://doi.org/10.1002/csr.132

Delmas, M. A., \& Burbano, V. C. (2011). The Drivers of Greenwashing. California Management Review, 54(1), 64-87. https://doi.org/10.1525/cmr.2011.54.1.64

Dietz, S., \& Neumayer, E. (2007). Weak and strong sustainability in the SEEA: Concepts and measurement. Ecological Economics, 61(4), 617-626. https://doi.org/10.1016/j.ecolecon.2006.09.007

Dietz, T., Ostrom, E., \& Stern, P. (2017). The struggle to govern the commons. International Environmental Governance, 302(December), 53-58. https://doi.org/10.4324/9781315092546-4

Donaldson, T., \& Preston, L. E. E. E. (1995). The Stakeholder Theory of the Corporation: Concepts, Evidence, and Implications. Academy of Management Review, 20(1), 65-91. https://doi.org/10.5465/amr.1995.9503271992

Emetumah, F. (2017). Modern Perspectives on Environmentalism: Ecocentrism and Technocentrism in the Nigerian Context. Asian Research Journal of Arts \& Social Sciences, 2(4), 1-9. https://doi.org/10.9734/ARJASS/2017/32821

Folke, C., Hahn, T., Olsson, P., \& Norberg, J. (2005). Adaptive governance of social-ecological systems. Annual Review of Environment and Resources, 30, 441-473. https://doi.org/10.1146/annurev.energy.30.050504.144511

Folke, C., Jansson, Å., Rockström, J., Olsson, P., Carpenter, S. R., Stuart Chapin, F., ... Westley, F. (2011). Reconnecting to the biosphere. Ambio, 40(7), 719-738. https://doi.org/10.1007/s13280-011-0184-y 
Friedman, M. (1970). The Social Responsibility of Business is to Increase its Profits. The New York Times Magazine. Retrieved from https://www.nytimes.com/1970/09/13/archives/a-friedman-doctrine-the-social-responsibility-of-business-isto.html

Fukuyama, F. (2013). What Is Governance? Governance (Oxford), 26(3), 347-368. https://doi.org/10.1111/gove.12035

Gibbs, D., \& O'Neill, K. (2017). Future green economies and regional development: A research agenda. Regional Studies, 51(1), 161-173. https://doi.org/10.1080/00343404.2016.1255719

Gibson, R. B. (2009). Beyond the pillars: Sustainability assessment as a framework for effective integration of social, economic and ecological considerations in significant decision-making. Tools, Techniques and Approaches for Sustainability, 8(3), 389-410. https://doi.org/10.1142/9789814289696_0018

Gladwin, T. N., Kennelly, J., \& Krause, T.-S. (1995). Shifting Paradigms for Sustainable Development: Implications for Management Theory. Academy of Management Review, 20(4), 874-907. https://doi.org/10.2307/258959

Goulder, L. H., \& Stavins, R. N. (2001). An eye on the future. Nature, 414(6863), 484. https://doi.org/10.1038/35107227

Gray, R. (2010). Is accounting for sustainability actually accounting for sustainability... and how would we know? An exploration of narratives of organisations and the planet. Accounting, Organizations and Society, 35(1), 47-62. https://doi.org/10.1016/j.aos.2009.04.006

Hammer, J., \& Pivo, G. (2017). The Triple Bottom Line and Sustainable Economic Development Theory and Practice. Economic Development Quarterly, 31(1), 25-36. https://doi.org/10.1177/0891242416674808

Hardin, G. (1968). The Tragedy of the Commons. Science, 162(3859), 1243-1248. https://doi.org/10.1126/science.162.3859.1243

Hawkins, T. R., Singh, B., Majeau-Bettez, G., \& Strømman, A. H. (2013). Comparative Environmental Life Cycle Assessment of Conventional and Electric Vehicles. Journal of Industrial Ecology, 17(1), 53-64. https://doi.org/10.1111/j.1530-9290.2012.00532.x

Hertwich, E. G. (2005). Consumption and the Rebound Effect-An Industrial Ecology Perspective. Journal of Industrial Ecology, 9(1), 85-98. https://doi.org/10.1162/1088198054084635

Herzberg, R. Q. (2020). Elinor Ostrom's Governing the Commons: Institutional Diversity, Self-Governance, and Tragedy Diverted. The Independent Review (Oakland, Calif.), 24(4), 627.

Hobbes, T. (1946). Leviathan, or, The matter, forme and power of a commonwealth, ecclesiasticall and civil. In M. Oakeshott (Ed.), Matter, forme and power of a commonwealth, ecclesiasticall and civil. B. Blackwell.

Hsiang, S., \& Kopp, R. E. (2018). An economist's guide to climate change Science. Journal of Economic Perspectives, 32(4), 3-32. https://doi.org/10.1257/jep.32.4.3

Illge, L., \& Schwarze, R. (2006). A Matter of Opinion: How Ecological and Neoclassical Environmental Economists Think about Sustainability and Economics. DIW Discussion Papers, 619.

Ivanova, D., Stadler, K., Steen-Olsen, K., Wood, R., Vita, G., Tukker, A., \& Hertwich, E. G. (2016). Environmental Impact Assessment of Household Consumption. Journal of Industrial Ecology, 20(3), 526-536. https://doi.org/10.1111/jiec.12371

Jabareen, Y. (2008). A new conceptual framework for sustainable development. Environment, Development and Sustainability, 10(2), 179-192. https://doi.org/10.1007/s10668-006-9058-z

Kates, R. W., Parris, T. M., \& Leiserowitz, A. A. (2005). What is sustainable development? Goals, indicators, values, and practice. Environment, 47(3), 8-21. https://doi.org/10.1080/00139157.2005.10524444

Monga, V. (2021, January 21). What Is the Keystone XL Pipeline and Why Did President Biden Issue an Executive Order to Block It? The Wall Street Journal. Retrieved from https://www.wsj.com/articles/what-is-the-keystone-xl-pipeline-and-why-did-president-biden-issue-an-execu tive-order-to-block-it-11611240342

Monks, R. A. G., \& Minow, N. (2011). Corporate governance (5th ed.). John Wiley \& Sons. https://doi.org/10.1002/9781119207238

Morrow, D., \& Rondinelli, D. (2002). Adopting Corporate Environmental Management Systems: Motivations 
and Results of ISO 14001 and EMAS Certification. European Management Journal, 20(2), 159-171. https://doi.org/10.1016/s0263-2373(02)00026-9

Nilsson, M., Griggs, D., \& Visbeck, M. (2016). Policy: Map the interactions between Sustainable Development Goals. Nature, 534(7607), 320-322. Nature Publishing Group. https://doi.org/10.1038/534320a

Olson, M. (1965). The logic of collective action; public goods and the theory of groups. Harvard University Press.

Oreskes, N., \& Conway, E. M. (2015). Merchants of Doubt: How a Handful of Scientists Obscured the Truth on Issues from Tobacco Smoke to Global Warming. Bloomsbury Publishing USA.

Ostrom, E. (2015). Governing the commons: The evolution of institutions for collective action. Cambridge University Press. https://doi.org/10.1017/CBO9781316423936

Pearce, D., Groom, B., Hepburn, C., \& Koundouri, P. (2003). Valuing the future. World Economy, 4(2), 121-141. https://doi.org/10.5840/asce19971716

Pelenc, J., \& Ballet, J. (2015). Weak Sustainability versus Strong Sustainability (pp. 1-4). Brief for GSDR 2015. United Nations (UN), $2005 . \quad$ Retrieved from https://sustainabledevelopment.un.org/content/documents/6569122-Pelenc-WeakSustainabilityversusStrong Sustainability.pdf

Porter, M. E., \& Kramer, M. R. (2006). Strategy \& society: The link between competitive advantage and corporate social responsibility. Harvard Business Review, 84, 78-92.

Porter, M., \& Kramer, M. (2011). Creating Shared Value: How to reinvent capitalism - and unleash a wave of innovation and growth. Harvard Business Review, January-February, 62-77. http://web.a.ebscohost.com

Richardson, B. (2011). Sovereign Wealth Funds and the Quest for Sustainability: Insights from Norway and New Zealand. Nordic Journal of Commercial Law, 2, 28.

Rittel, H. W. J., \& Webber, M. M. (1973). Dilemmas in a General Theory of Planning. Policy Sciences, 4, 155-169. https://doi.org/10.1080/01636609209550084

Schandl, H., Hatfield-Dodds, S., Wiedmann, T., Geschke, A., Cai, Y., West, J., ... Owen, A. (2016). Decoupling global environmental pressure and economic growth: Scenarios for energy use, materials use and carbon emissions. Journal of Cleaner Production, 132, 45-56. https://doi.org/10.1016/j.jclepro.2015.06.100

Seyfang, G. (2009). The new economics of sustainable consumption: Seeds of change. Palgrave Macmillan. https://doi.org/10.1057/9780230234505

Sikka, P. (2010). Smoke and mirrors: Corporate social responsibility and tax avoidance. Accounting Forum, 34(3-4), 153-168. https://doi.org/10.1016/j.accfor.2010.05.002

Singh, S. J., \& Eisenmenger, N. (2010). How Unequal is International Trade? An Ecological Perspective Using Material Flow Accounting. Journal Für Entwicklungspolitik, 26(4), 57-88. https://doi.org/10.20446/JEP-2414-3197-26-4-57

Smil, V. (2017). Energy and Civilization: A History. MIT Press. https://doi.org/10.7551/mitpress/9780262035774.001.0001

Spaargaren, G., \& Mol, A. P. J. (2013). Carbon flows, carbon markets, and low-carbon lifestyles: Reflecting on the role of markets in climategovernance. Environmental Politics, 22(1), 174-193. https://doi.org/10.1080/09644016.2013.755840

Stafford-Smith, M., Griggs, D., Gaffney, O., Ullah, F., Reyers, B., Kanie, N., ... O'Connell, D. (2017). Integration: the key to implementing the Sustainable Development Goals. Sustainability Science, 12(6), 911-919. https://doi.org/10.1007/s11625-016-0383-3

Starik, M., \& Kanashiro, P. (2013). Toward a Theory of Sustainability Management: Uncovering and Integrating the Nearly Obvious. Organization and Environment, 26(1), 7-30. https://doi.org/10.1177/1086026612474958

Steffen, W., Richardson, K., Rockström, J., Cornell, S. E., Fetzer, I., Bennett, E. M., ... Sörlin, S. (2015). Planetary boundaries: Guiding human development on a changing planet. Science, 347(6223). https://doi.org/10.1126/science.1259855

Steffen, W., Rockström, J., Richardson, K., Lenton, T. M., Folke, C., Liverman, D., ... Schellnhuber, H. J. (2018). Trajectories of the Earth System in the Anthropocene. Proceedings of the National Academy of Sciences of 
the United States of America, 115(33), 8252-8259. https://doi.org/10.1073/pnas.1810141115

Subramanian, S. (2019, July 23). Is fair trade finished? The Guardian. Retrieved from https://www.theguardian.com/business/2019/jul/23/fairtrade-ethical-certification-supermarkets-sainsburys

United Nations. (n.d.). Take Action for the Sustainable Development Goals. Retrieved September 30, 2020, from https://www.un.org/sustainabledevelopment/sustainable-development-goals/

United Nations Office for Sustainable Development. (2020). The SDG Partnership Guidebook: A practical guide to building high impact multi-stakeholder partnerships for the Sustainable Development Goals. Retrieved from

https://sustainabledevelopment.un.org/content/documents/2698SDG_Partnership_Guidebook_1.01_web.pdf

Van der Byl, C., \& Slawinski, N. (2015). Embracing Tensions in Corporate Sustainability: A Review of Research from Win-Wins and Trade-Offs to Paradoxes and Beyond. Organization \& Environment, 28(1), 54-79. https://doi.org/10.1177/1086026615575047

van der Ven, H., Rothacker, C., \& Cashore, B. (2018). Do eco-labels prevent deforestation? Lessons from non-state market driven governance in the soy, palm oil, and cocoa sectors. Global Environmental Change, 52(July), 141-151. https://doi.org/10.1016/j.gloenvcha.2018.07.002

Vörösmarty, C. J., McIntyre, P. B., Gessner, M. O., Dudgeon, D., Prusevich, A., Green, P., ... Davies, P. M. (2010). Global threats to human water security and river biodiversity. Nature, 467(7315), 555-561. https://doi.org/10.1038/nature09440

Wang, R., Moreno-Cruz, J., \& Caldeira, K. (2017). Will the use of a carbon tax for revenue generation produce an incentive to continue carbon emissions? Environmental Research Letters, 12(6). https://doi.org/10.1088/1748-9326/aa6e8a

Westley, F., Olsson, P., Folke, C., Homer-Dixon, T., Vredenburg, H., Loorbach, D., ... Van Der Leeuw, S. (2011). Tipping toward sustainability: Emerging pathways of transformation. Ambio, 40(7), 762-780. https://doi.org/10.1007/s13280-011-0186-9

Wright, C., \& Nyberg, D. (2017). An inconvenient truth: How organizations translate climate change into business as usual. Academy of Management Journal, 60(5), 1633-1661. https://doi.org/10.5465/amj.2015.0718

\section{Notes}

Note 1. These factors are derived from the PASTEL framework used to analyze organizational performance.

Note 2. Environmental and corporate governance are central to ongoing SUSM discourse, as:

1) SUSM literature highlights a need for further scholastic and practical advancement in governance systems that are capable of balancing socio-economic and environmental interests (Costanza et al., 2000; T. Dietz et al., 2017; Folke et al., 2005, 2011; Westley et al., 2011).

2) SUSM literature denotes a disconnect between environmental researchers-who have documented how human activity connects to the decay of Earth systems (Hsiang \& Kopp, 2018; Steffen et al., 2018; Vörösmarty et al., 2010) - and governance stakeholders have largely adopted a "business-as-usual" approach to environmental stewardship (Wright \& Nyberg, 2017, 1657).

\section{Copyrights}

Copyright for this article is retained by the author, with first publication rights granted to the journal.

This is an open-access article distributed under the terms and conditions of the Creative Commons Attribution license (http://creativecommons.org/licenses/by/4.0/). 